\title{
FEM ANALYSIS OF ANCHORED SHEET PILE QUAY WALL: A CASE STUDY ON THE FAILURE OF WQ-7 BERTH OF VISAKHAPATNAM PORT
}

\author{
Mohamed Faizur Rahaman Khazi ${ }^{1}$, Mahammood Vazeer ${ }^{2}$ \\ ${ }^{I}$ Department of Civil Engineering, College of Engineering, Andhra University, Visakhapatnam-530 003, A.P., India \\ ${ }^{2}$ Department of Civil Engineering, College of Engineering, Andhra University, Visakhapatnam-530 003, A.P., India
}

\begin{abstract}
In this paper anchored sheet pile wall is analyzed by Finite Element method (FEM) and SAP2000 is used for the analysis. This method uses soil spring models for soil structure interaction(SSI) and sheet pile is modeled as beam element and the embedded part of the pile as a beam on Winkler foundation. The method is validated with the examples available in literature. The method is used for the case study of the failure of WQ-7 berth of Visakhapatnam Port which failed immediately after construction during post 2004 Indian Ocean tsunami. Seismic and non-seismic loading conditions are considered in the analysis along with the effect of liquefaction. In the investigation during the analysis it is found that the failure of the structures is not due to liquefaction rather may be due to basal heave failure on account of inadequate pile penetration and mud flow, which needs further investigation.
\end{abstract}

Keywords:Sheet pile wall; finite element method; Winkler foundation; liquefaction; basal heave.

\section{INTRODUCTION}

The anchored sheet-pile wall analysis has to address both geotechnical and structural requirements, which involves evaluation of gross stability and stresses induced in structural components. The gross stability is evaluated to determine resistance to overturning and sliding; basal heave, control of ground water and resistance to ground movements. The stresses due to bending moments, web shear and axial force are evaluated for the sheet-pile, anchor, and tie-rod.

There are several methods for analyzing anchored sheet pile quay walls including the two early methods; free earth support method and fixed earth support method. These methods are used with simplified assumptions of active pressure for filled side and passive pressure for free side below dredge line. These methods have been included in many of the codes around the world including India Standard Code IS 9527, 2002. For the seismic analysis pseudo-static approach is adopted by many codes where the earth pressure due to backfill is calculated using the Mononobe-Okabe equation.

"There is no exact method to analyze or design a sheet pile type of wall. Both field observation and laboratory model test show that there is a complex interaction of (as a minimum) construction method (install and backfill or install and excavate the free side), excavation depth, stiffness of wall material, type and state of retained soil and passive soil resistance. With anchored wall, there is also the anchor geometry; initial anchor pre-stress at construction stage when the anchor is installed and the behavior of the part of the wall above anchor rod all plays a significant role.
The conventional free and fixed-earth methods are an oversimplification of an extremely complex problem, relied totally on rigid body statics, and are based entirely on the assumptions of an active earth pressure above dredge line and passive earth pressure below. Wall and anchor stiffness do not enter the Equation of equilibrium."(Bowles $\mathrm{J}$ E, 1997).

The use of soil structure interaction models and finite element techniques to analyze earth structures is becoming increasingly common, especially for large or complex structures. The technical standards for port and harbor facilities in Japan (Ministry of Transport, Japan, 1999) included effective-stress analysis to assess seismic performance of quay structures (Nozu A, et al, 2004). The use of soil spring models and finite element methods of analysis account for the interaction, or flexibility, of the support system directly and hence do not require a predetermined earth pressure distribution model (Michael J. Garlich, 2009). Availability of FEM based software have made the job more easy and accurate. SAP2000 offers lot of options for modeling the structure with different seismic and non-seismic load combinations.

In this paper FEM approach for the analysis of anchored sheet pile wall using SAP2000 is described as an alternate comprehensive procedure. The method uses simple beam spring model with SPT values as spring constants yet captures the basic mechanism of pile behavior. The method is used for the case study of the failure of WQ-7 berth of Visakhapatnam Port which failed immediately after construction. 


\section{METHOD OF ANALYSIS}

The Finite Element Method (FEM) of analysis of sheet pile quay walls presented here is the most efficient and rational method. This method uses a beam spring model for the embedded part of the sheet pile below the dredge line. Sheet pile is modeled as beam element connected to a series of springs representing the lateral stiffness of the embedded soil below the dredge line based on the concept of WinklerBeam model. This finite element (FE) beam-spring model easilyincorporates more complex soil layering and with a FEM based software can be analyzed for different loading conditions. Lateral earth pressure above the dredge line, surcharge pressure and differential water pressure can be modeled along with birthing and mooring forces. The model can also be subjected to wave forces and seismic forces.

\subsection{Soil Spring Constants}

The stiffness of the soil springs are evaluated using correlations with the SPT blow count, $\mathrm{N}$ by first finding the subgrade reaction coefficient, $\kappa$, using an empirical formula given by Architectural Institute of Japan 2001 and then stiffness $\mathrm{K}$ is evaluated by multiplying subgrade reaction with area of the beam element between the nodes:

$$
x=56\left(\mathrm{~N}_{78}\right) \mathrm{D}_{0}^{-34} \quad\left[\mathrm{MN} \mathrm{m}^{3}\right](1)
$$

where, $\mathrm{N}_{78}$ is the SPT blow count corresponding to $78 \%$ of the theoretical free fall energy and $D_{0}$ is the pile diameter in $\mathrm{cm}$.

In liquefied soil the stiffness $\mathrm{K}$ is degraded by a factor $\beta$ which is less than one. From different case studies and experimental tests by many researchers, the stiffness degradation of liquefied soils can be assumed to vary between $\beta=1 / 10$ and $1 / 50$ (Bowen $\mathrm{J} \mathrm{H}$, et al 2008).

\subsection{Failure Modes of Sheet Pile walls}

There are variety of potential modes of geotechnical and structural failure of anchored sheet pile walls both due to general loadings as well as seismic loading conditions.

1. Deep-seated failure, a potential rotational failure of an entire soil mass containing the sheet pile system, which is independent of the structural characteristics of the wall and/or anchor. The factor of safety against such mode of failure is assessed through slope stability analysis.

2. Wall rotational failure due to inadequate pile penetration, where the Lateral pressures from soil and/or water exerted on the sheet pile wall tend to cause rotation of the structure.

3. Structural failure of sheet pile, anchor pile or anchor due to overstressing. Each structural component contributes to the stability of the whole structure. Excessive displacements of the anchor are undesirable. A small movement of the anchor, however, contributes to reducing the tension in the tie rods

4. Failure due to earthquake and liquefaction: There are four possible modes of failure identified in anchored sheet pile walls due to liquefaction depending on the extent of loose, saturated sandy soils relative to the position and geometry of the wall as shown in figure 1 . The first three modes of failure have been identified during the past earthquakes where as there is no case history that fits the fourth failure mode due to the existing designs which consider firmly embedded walls, which are designed for a fraction of bending moment induced at the free-earth support conditions (PIANC, 2001).

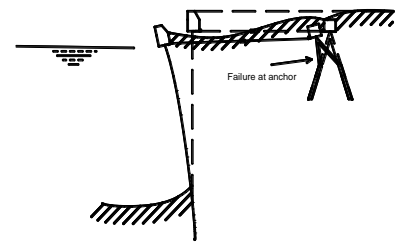

a) Failure at anchor

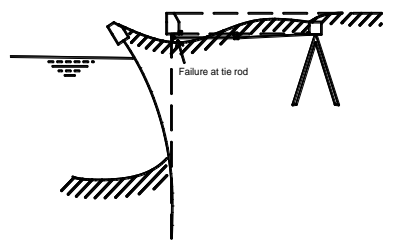

c) Failure at tie rod

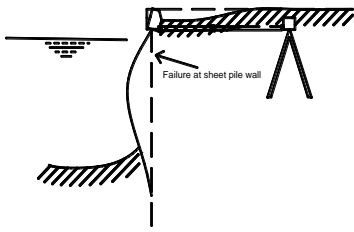

b) Failure at sheet pile wall

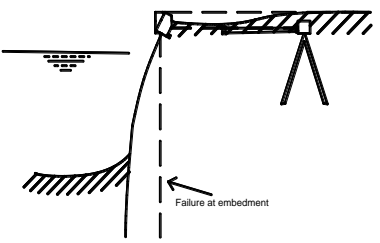

d) Failure at embedment
Fig 1: Possible modes of failure in anchored sheet pile walls due to liquefaction

\subsection{Validation of the Method}

The method has been validated from an example given in the book 'Foundation Analysis and Design' fifth edition by Joseph E Bowles (1997). In the example a PZ35 steel sheet pile section is used to support soil as shown in the figure $2 \mathrm{a}$ and the same is modeled using SAP2000 (Figure 2b). In the book the author uses a program FADSPABW (B-9) and the results of which are compared with the results of model developed and analyzed using SAP2000. Model bending moment diagram (BMD), shear force diagram (SFD) and the deflection diagram are compared and have been found that both the programs give the same result (Figure $2 \mathrm{c}$ to $2 \mathrm{~h}$ ). Hence the SAP2000 model and the method used are validated.

\section{CASE STUDY}

The Port of Visakhapatnam, India, has constructed 22 berths in 2005. Berth WQ-7 is the extended northern arm of inner harbor, which was completed in April 2005 using 2350 metric tons of steel sheet piles. The typical structural solution used for this work consisted of vibro driven steel sheet piles, anchored at the top with post-tensioned steel anchor sheet piles. The quay wall consisted of a combined HZ 975 AZ-14, S 430 GP type sheet pile wall, anchored by means of anchor steel sheet pile AZ-18, S 320 GP (Figure3, ArcelorMittal Sheet Piling, 2014). The geotechnical data used in the analysis are given in Table 1. 
This quay wall, used only once after construction, showed a sudden simultaneous failure along two segments separated by about $1.50 \mathrm{~m}$. This failure lead to displacement of the top beam toward the sea and caused surface subsidence of the ground behind the sheet piles (Table 2). Early investigations showed that failure had not been caused by insufficient resistance of the anchor piles or failure of tie rod. The reason of failure remained to be investigated and hence the present study is aimed at investigating liquefaction as a possible reason for the failure of the steel sheet pile.

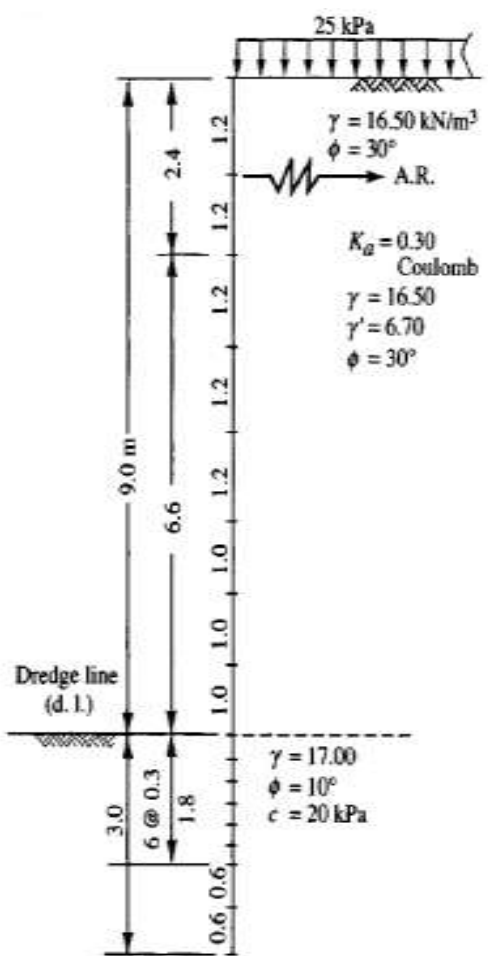

a) Bowles' example

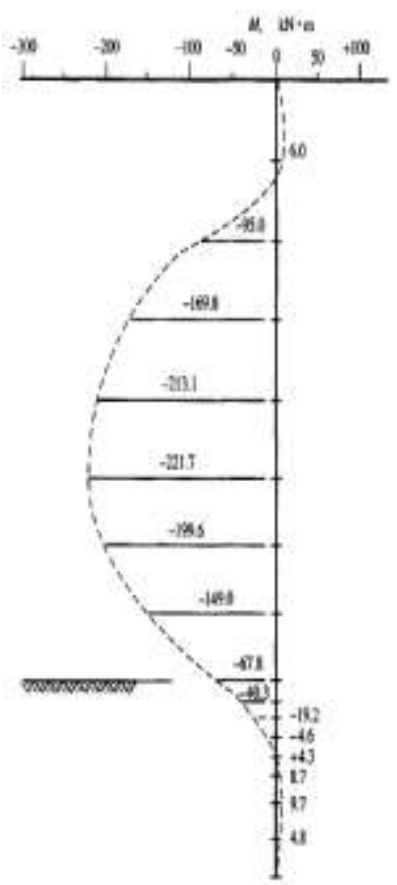

c) BMD from Bowles' Result

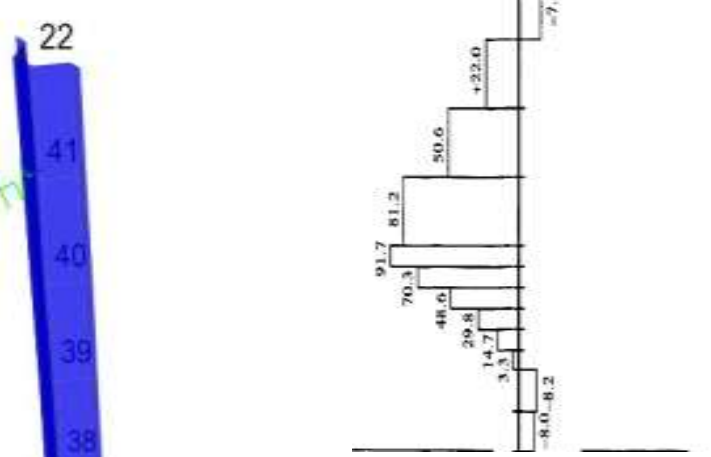

e) SFD from Bowles' Result

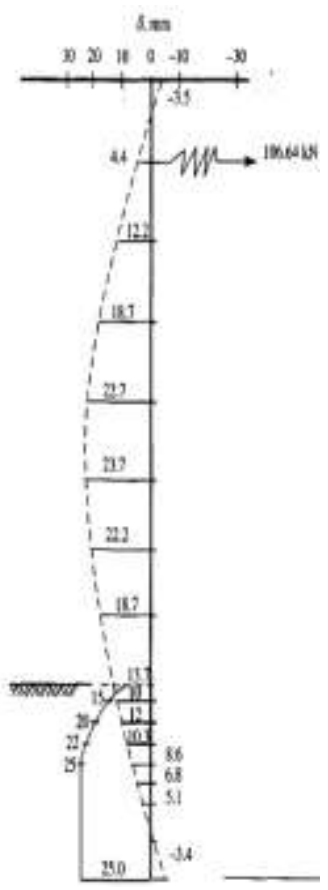

g) Deflection from
Bowles' Result

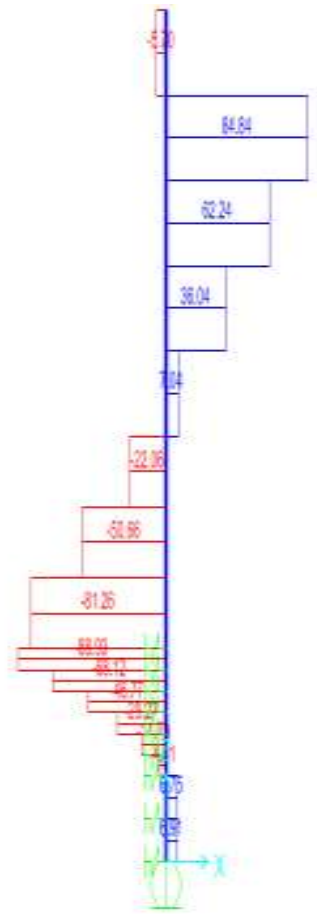

f) SFD from SAP2000 result

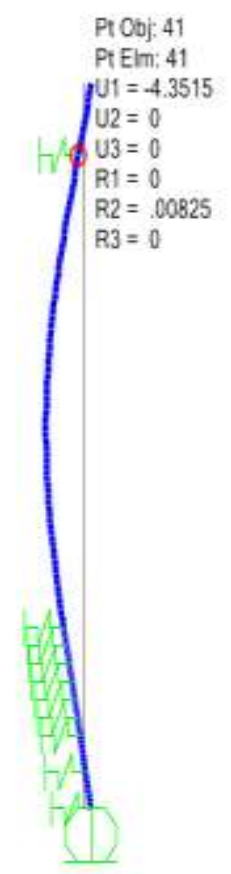

h) Deflection from SAP2000 result
Fig 2 (a to h): Bowles' example results are compared with the SAP2000 model results for validation. 


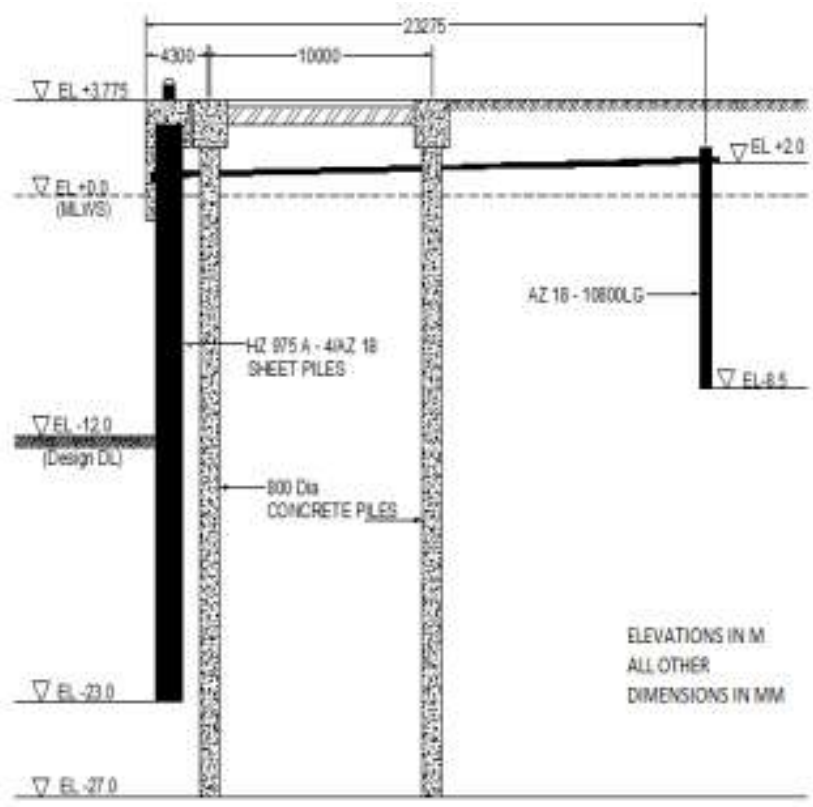

Table 1: Bore Log Data obtained at WQ-7(ArcelorMittal, 2014)

\begin{tabular}{|l|l|l|l|}
\hline \multicolumn{2}{|c|}{ Ground R.L } & $\begin{array}{l}\text { Visual Description } \\
\text { of strata }\end{array}$ & N Values \\
\hline From & To & & \\
\hline+2.00 & +0.00 & Reddish gravelly soil & 10 \\
\hline+0.00 & -8.00 & Fine sand with silt & 6 \\
\hline-8.00 & -17.00 & Blackish soft clay & 4 \\
\hline-17.00 & -20.5 & Brownish stiff clay & 35 \\
\hline-20.5 & -24.00 & Highly weathered rock & $>50$ \\
\hline-24.00 & -27.38 & Hard rock with fractures & $>50$ \\
\hline
\end{tabular}

Fig 3: Extension of berth WQ-7 in the northern arm of inner harbor at Visakhapatnam Port.

Table 2: Sheet Pile Deflections at different chainages after failure

\begin{tabular}{|l|l|l|l|l|l|}
\hline Chainage (4.5m) & 51 & 50 & 49 & 48 & 47 \\
\hline Displacement (mm) & 100 & 200 & 230 & 240 & 294 \\
\hline Chainage (4.5m) & 46 & 45 & 44 & 43 & 42 \\
\hline Displacement (mm) & 333.5 & 350 & 380 & 490 & 640 \\
\hline Chainage (4.5m) & 41 & 40 & 39 & 38 & 37 \\
\hline Displacement (mm) & 810 & 1000 & 1100 & 1030 & 1000 \\
\hline Chainage (4.5m) & 36 & 35 & 34 & 33 & 32 \\
\hline Displacement (mm) & 960 & 910 & 860 & 840 & 830 \\
\hline Chainage $(4.5 \mathrm{~m})$ & 31 & 30 & 29 & 28 & 27 \\
\hline Displacement (mm) & 820 & 810 & 810 & 810 & 800 \\
\hline Chainage $(4.5 \mathrm{~m})$ & 26 & 25 & 24 & 23 & 22 \\
\hline Displacement (mm) & 790 & 800 & 820 & 800 & 740 \\
\hline Chainage $(4.5 \mathrm{~m})$ & 21 & 20 & 19 & 18 & 17 \\
\hline Displacement (mm) & 710 & 660 & 620 & 570 & 480 \\
\hline Chainage (4.5m) & 16 & 15 & 14 & 13 & 12 \\
\hline Displacement (mm) & 415 & 360 & 200 & 189 & 170 \\
\hline
\end{tabular}

In an independent study, SwarnaLatha and Vazeer Mahammood (2012) obtained the liquefaction index values for the soil in the site which has fine sand with silt ( 0.00 to 8.00 levels), the liquefaction possibility varied from "likely occurs" to "certainly occurs" for $0.1 \mathrm{~g}$ to $0.3 \mathrm{~g}$ peak ground acceleration (PGA) respectively when tested for different fines percent varying between less than $5 \%$ to $35 \%$.

In this case study different critical combination of loads is considered to assess failure possibility. Different loads considered in the combinations are dead load, active earth pressure, differential water pressure, anchor pull, surcharge load and response spectrum load. To check the possibility of failure due to liquefaction in second layer soil springs' stiffness is degraded in the model.

\section{RESULTS}

Figure 4 shows the modeling and sheet pile analysis result under critical load combinations when the anchor fails. It has been observed that a maximum of $679.64 \mathrm{~mm}$ deflection occurs at the top of sheet pile if the anchor fails (Figure 4c). 


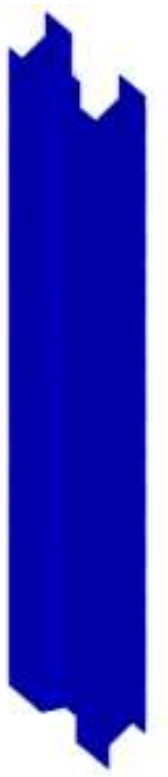

a. Structural Model

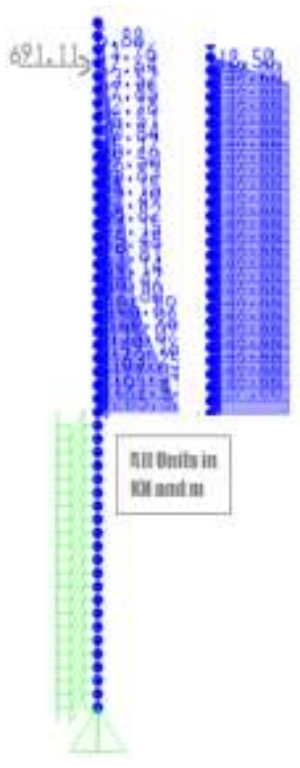

b. Soil-Structure-Water- Interaction Model

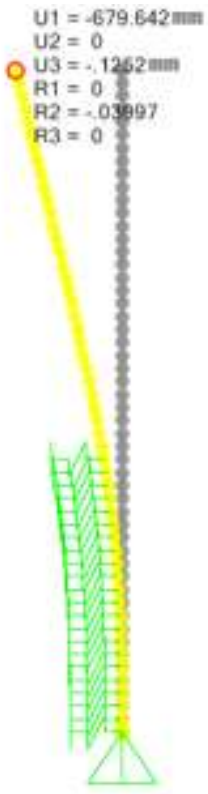

c. Deflection when anchor fails

Fig 4: Modeling and Analysis of sheet pile under different loading combinations

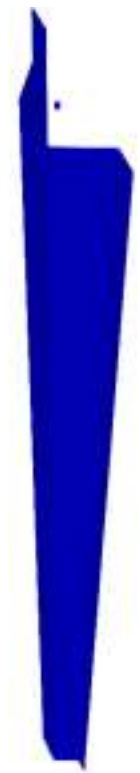

a. Structural Model

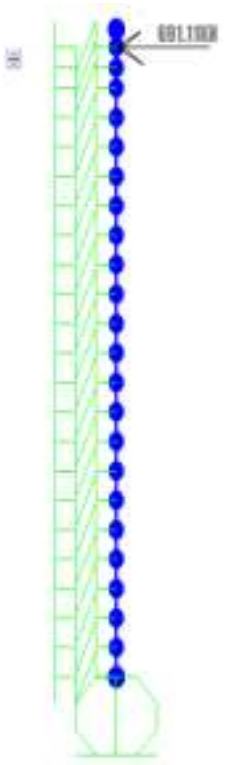

b. Soil-Structure-Interaction Model for liquefaction

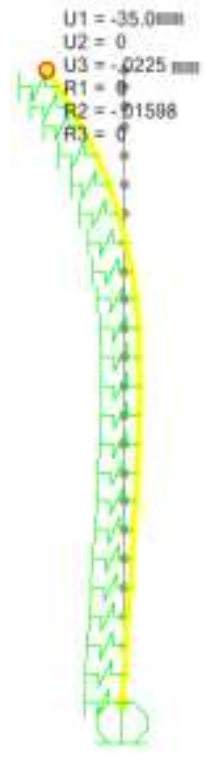

c. Deflection under liquefaction

Fig 5: Modeling and Analysis of anchor sheet pile under liquefaction

Figures 5 and 6 show the modeling of anchor sheet piles and concrete piles respectively under liquefaction conditions. It has been observed that anchor sheet pile deflects only $35 \mathrm{~mm}$ at the top (Figure 5c), where as concrete piles do not show any significant deflection either laterally or vertically (Figure 6c).

When there is improper penetration of sheet piles in the rock (weathered rock), there will be mudflow beneath the sheets from landwards towards the sea side during dredging operation. Under such circumstances the deck-concrete pile system will fail and deck slab load will be directly transferred to the backfill rather than to the concrete piles. This scenario is assumed by the authors and the sheet pile is modeled by taking these forces as surcharge loads (Figure 7a) and analysis is carried out. It has been found that the deflection at the top was more than one meter (Figure $7 \mathrm{~b}$ ) which resembles the actual deflections measured in the field 


\section{CONCLUSION}

1. Concrete piles and deck slab system was modeled in SAP2000 and analyzed for the effect of liquefaction, it was found that the system does not fail due to liquefaction.

2. Anchor sheet pile was also modeled in SAP2000 and analyzed for the effect of liquefaction and was found that only a maximum of $35 \mathrm{~mm}$ deflection occurred at top of anchor sheet pile.

3. As the phenomenon of liquefaction was temporary and only during the driving of sheet pile it can be concluded that failure may not be due to liquefaction.
4. As it has been observed that the concrete piles have deflected towards the sheet piles bringing directly the deck slab to rest on the backfill causing vertical settlement. To take this effect into consideration another analysis was made. Dead and live loads

5. from deck slab are considered as surcharge loads approximately $150 \mathrm{kN} /$ square meter. This analysis gave deflection of more than a meter at the top of the sheet pile.

6. From this study it can be concluded that the failure is not due to liquefaction rather may be due to basal heave or mud slide of soft clay layer below the fine sand layer during or after the sheet pile driving.

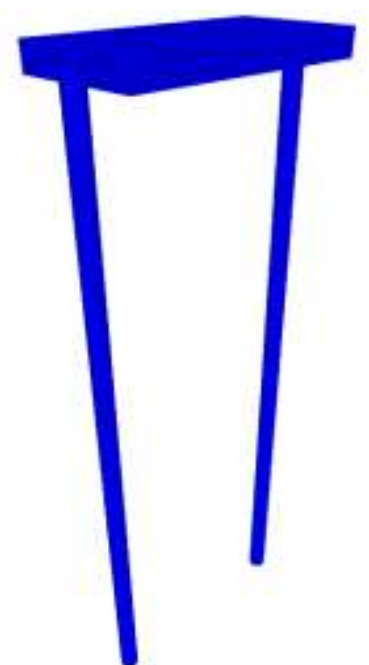

a.

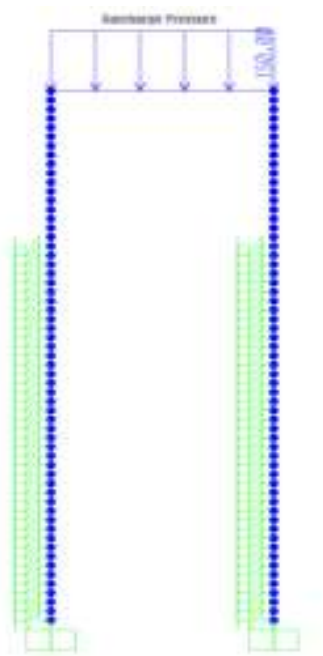

b. Soil-StructureInteraction Model for liquefaction

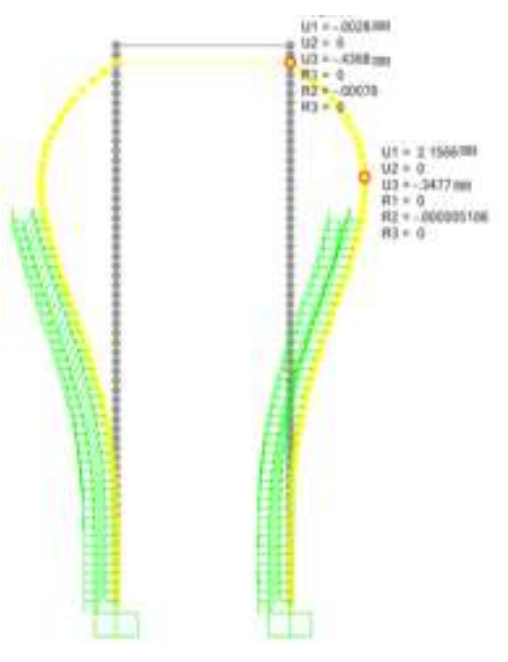

c. Deflection under liquefaction

Fig 6: Modeling and Analysis of concrete pile-deck system under liquefaction

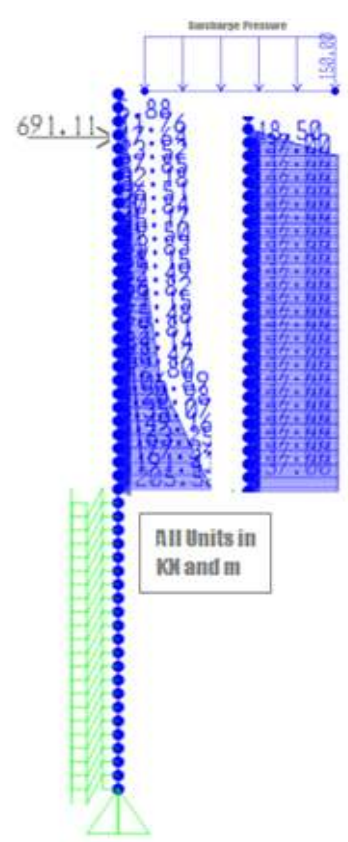

a. Soil-Structure-Interaction Model when concrete piles fail due to basal heave

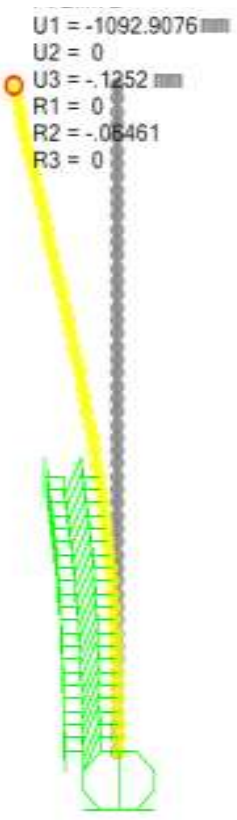

b. Deflection when concrete piles fail due to basal heave

Fig 7: Failure of sheet piles due to basal heave caused by improper penetration of sheet piles 


\section{REFERENCES}

[1] ArcelorMittal Commercial Sheet Piling (2014) The HZ® -M Steel Wall System 2014, Luxembourg.

[2] Architectural Institute of Japan (AIJ) (2001) Recommendations for designing of building foundations, Tokyo (in Japanese).

[3] Bowles, J.E. (1997) Foundation Analysis and Design: Fifth Edition 2012; McGraw-Hill Companies Inc N.Y. USA.

[4] Bowen J H and Cubrinovski M (2008)Pseudo-Static Analysis of Piles in Liquefiable Soils: Parametric Evaluation of Liquefied Layer Properties. Bulletin of the New Zealand Society for Earthquake Engineering, Vol. 41, No. 4, December 2008.

[5] IS 9527 Part 32002 Code of practice for design of port and harbors for sheet pile walls Bureau of Indian Standard, New Delhi, India.

[6] Michael J. Garlich (2009)Assessing U.S. practices for waterfront steel sheet pile walls. Port technology international 21, mooring and berthing assessing, Collins Engineers, Inc., Chicago, Illinois, USA.

[7] Ministry of Transport Japan (1999) Design Standard for Port and Harbor Facilities and Commentaries, Japan Port and Harbor Association (in Japanese). English edition (2001) by the Overseas Coastal Area Development Institute of Japan.

[8] NOZU A, ICHII K, and SUGANO T (2004) Seismic design of port structures. Journal of Japan Association for Earthquake Engineering, Vol.4, No.3 (Special Issue).

[9] PIANC (2001) Seismic Design Guidelines for Port Structures, Working Group No. 34 of the Maritime Navigation Commission. International Navigation Association, A.A. Balkema, Rotterdam, The Netherlands.

[10] SAP2000 Computers and Structures Inc. 1995 University Avenue Berkeley, California 94704, USA.

[11] Swarna Latha and Vazeer Mahammood (2012)Liquefaction Studies for Visakhapatnam City. National Conference on Recent Advances in GeoSciences. Engineering and Technology (NCRAGE) December 2012, JNTU Kakinada, India. 